\title{
Clinical Evaluation of Children with Kawasaki Disease Hospitalized in Our Clinic: A Retrospective Study
}

\author{
Mehmet Gündüz, Yasemin Akın, Esra Çelik Kuzaytepe, Ayşe Karaaslan, \\ Esra Çetinkaya Polatoğlu, Hüseyin Kıyak
}

Department of Pediatrics, Kartal Dr. Lütfi Kırdar Training and Research Hospital, İstanbul,Turkey

Submitted: 25.05.2017 Accepted: 02.01.2018

Correspondence: Mehmet Gündüz, Kartal Dr. Lütfi Kırdar Eğitim ve Araştırma Hastanesi, Çocuk Sağlığı ve Hastalıkları Kliniği, İstanbul, Turkey

E-mail:drmgunduz@gmail.com

四:

Keywords: Children; clinical findings; complete type; incomplete type; Kawasaki disease.

\section{ABSTRACT}

Objective: Kawasaki disease is one of the most common childhood forms of vasculitis. The aim of this study was to evaluate children with Kawasaki disease hospitalized in our pediatrics department over a 6-year period.

Methods: A total of 39 children treated for Kawasaki disease in the pediatric department between January 2008 and December 2013 were evaluated retrospectively.

Results: Of 39 patients, 29 (74.3\%) were male and 10 (25.6\%) were female. The male/ female ratio was 2.9. The mean patient age was $31.82 \pm 20.31$ months. In all, 2 patients were diagnosed with Kawasaki disease in 2008, 6 in 2009, 5 in 2010, 7 in 201 I, 10 in 2012 and 9 in 2013 . Lesions of the oral cavity were found in $89.7 \%$, extremity changes were observed in $61.5 \%$, conjunctivitis was seen in $76.9 \%$, polymorphous exanthema was detected in $74.4 \%$, and lymphadenopathy was present in $61.5 \%$ of the patients. In 22 patients, coronary artery disease was detected on an echocardiogram. According to the Kawasaki disease diagnostic criteria, $\mathbf{6 4 . 1 \%}$ were diagnosed as complete Kawasaki disease and $35.9 \%$ as incomplete. Myocardial infarction or death did not occur.

Conclusion: The cardiovascular complications of Kawasaki disease can be prevented with early diagnosis and treatment in both complete and incomplete cases.

\section{INTRODUCTION}

Kawasaki disease, first described by Tomisaku Kawasaki ${ }^{[1]}$ in 1967, is an acute, febrile, multisystemic vasculitis with mucocutaneous findings.Diagnosis of this disease, which primarily involves the medium-sized muscular arteries, is made based on the presence of systemic inflammation, evidenced by fever and signs of mucocutaneous inflammation. A fever lasting for at least 5 days, and 4 of the classic signs: edema in the hands and feet, palmar and plantar erythema, periungal peeling of the fingers and toes, polymorphic rash, non-exudative bulbar conjunctivitis, oral mucosal changes, and unilateral cervical lymphadenopathy, are the basis of diagnosis. ${ }^{[2]}$ These findings do not generally appear all at the same time, and there is no typical chronological pattern. In patients who have a fever persisting for $\geq 5$ days and with 2 or 3 of the clinical criteria of Kawasaki disease, incomplete Kawasaki disease should be considered. Especially in children younger than 6 months of age with an unexplained fever lasting for more than 7 days, an echocardiographic examination should be performed. ${ }^{[3,4]}$ It is difficult to make the diagnosis of incomplete Kawasaki disease unless coronary artery anomalies are detected. Although its etiology is not known, the detection of epidemics at certain periods, and a higher incidence rate in certain age groups suggest that this disease may be associated with infections. In addition, some studies have suggested the presence of a genetic predisposition. ${ }^{[5]}$ Coronary artery involvement is the most important complication of the disease. In advanced phases of the disease, coronary artery dilation, aneurysm, and myocardial ischemia may occur, and 
rarely, myocardial infarction and aneurysmal rupture may develop. ${ }^{[6,7]}$ There is no specific treatment for Kawasaki disease. In the early stages, intravenous immunoglobulin (IVIG) treatment can prevent the complication of coronary artery involvement. ${ }^{[8]}$ The basic objective of the treatment is to reduce inflammation of the coronary artery and myocardium, and to prevent thrombosis by inhibiting platelet aggregation.

The aim of this study was to examine the demographic characteristics and the clinical, laboratory, and echocardiographic findings of cases with the established diagnosis of Kawasaki disease treated in the clinic during a period of 6 years.

\section{MATERIAL AND METHODS}

This was a retrospective study of patients who were hospitalized in the clinic of children's health and diseases between January I, 2008 and December 3I, 20I 3 with a diagnosis of Kawasaki disease. Thirty-nine patients of 24,86 I who were hospitalized in the service were included in the study. Diagnoses of incomplete Kawasaki disease and classic Kawasaki disease were made based on the diagnostic criteria published by the American Heart Association in 2004. ${ }^{[3]}$ Demographic characteristics, electrocardiographic findings, and laboratory data of hemoglobin ( $\mathrm{Hgb})$, hematocrit (Hct), platelet (plt) and white blood cell (WBC) counts, erythrocyte sedimentation rate (ESR), C-reactive protein (CRP), alanine aminotransferase (ALT), aspartate transaminase (AST), serum albumin, and sodium values were recorded from patient files. The incidence of classic diagnostic criteria of the patients was evaluated and the duration of fever was recorded.

Patients who received treatment within the first 10 days after the onset of fever were considered to be in the acute phase of the disease, while patients who received treatment more than 10 days after the onset of a febrile episode were classified as subacute. ${ }^{[3]}$ Clinical findings other than the classic diagnostic criteria were also determined. The distribution of the disease by year, season, and month was calculated. Full blood count results of $\mathrm{Hgb} \leq \mathrm{I} \mathrm{I} \mathrm{mg} / \mathrm{dL}$, WBC $\geq 12000 / \mathrm{mm}^{3}$, plt $\geq 450000 / \mathrm{mm}^{3}$, ALT and AST $\geq 40$ $\mathrm{IU} / \mathrm{L}$, albumin $\leq 3.5 \mathrm{~g} / \mathrm{dL}$, sodium $\leq 135 \mathrm{mmol} / \mathrm{L}$, ESR $\geq 20$ $\mathrm{mm} / \mathrm{hour}$, and CRP $\geq 5 \mathrm{mg} / \mathrm{dL}$ were found to be pathological. The pediatric cardiology department was consulted, and echocardiography results were analyzed. The echocardiographic and clinical findings of patients diagnosed with complete and incomplete Kawasaki disease were compared. After the establishment of the diagnosis, all of the patients received intravenous immune globulin at a dose of $2 \mathrm{~g} / \mathrm{kg}$ as a 12-hour infusion, and oral $80 \mathrm{mg}$ acetylsalicylic acid administered in 4 doses. Patients with recurrent fever or persistent fever despite treatment received a second dose of IVIG therapy. If the febrile episodes persisted despite the second dose of IVIG treatment, the patients were given methylprednisolone at daily doses of $2 \mathrm{mg} / \mathrm{kg}$. Aspirin treatment was administered in a larger dose at the time of diagnosis and maintained for I to 2 weeks, followed by antiaggregant doses of aspirin (3-5 mg/kg/day, single dose).

The statistical analyses were performed using SPSS for Windows, Version I5.0 (SPSS, Inc., Chicago, IL, USA). Student's t-test was used to compare 2 groups and a paired sample t-test was used for intra-group comparison of descriptive statistical methods (mean, SD, frequency). For the comparison of qualitative data, a chi-square test, Fisher's exact chi-square test, Yates continuity correction, and McNemar's test were employed. Statistical significance was evaluated at a level of $p<0.05$.

\section{RESULTS}

The study population consisted of 29 male and 10 female patients with a male/female ratio of 2.9. The mean age at diagnosis was $31.82 \pm 20.31$ months (range: 3-89 months). Two (5.1\%) patients were younger than 6 months of age, while $87.2 \%(n=34)$ were aged between 6 and 60 months and $7.7 \%(n=3)$ of the patients were more than 60 months of age.

The distribution of diagnoses according to year was 2008: $n=2,5.1 \%$; 2009: $n=6,15.4 \% ; 2010: n=5,12.8 \% ; 2011: n=7$, 17.9\%; 2012: $n=10,25.6 \%$; and 2013: $n=9,23.1 \%$. The seasonal distribution of diagnoses was summer: $n=15,38.5 \%$; winter: $n=10,25.6 \%$; spring: $n=7,17.9 \%$; and autumn: $n=7$, 17.9\%. The most common month of diagnosis was June $(n=6 ; 15.4 \%)$.

In this study, 33 patients $(84.6 \%)$ were diagnosed during the acute phase and 6 (15.4\%) in the subacute phase of the disease. All of the patients had a fever. The duration of the fever ranged between 4 and I 5 days (mean: 6.92 \pm 2.99 days). Oral mucosa lesions on the lips $(n=35 ; 89.7 \%)$, extremity lesions $(n=24 ; 61.5 \%)$, conjunctivitis $(n=30$; $76.9 \%)$, skin rash $(n=29 ; 74.4 \%)$, and lymphadenopathy $(n=24 ; 61.5 \%)$ were observed (Table I). Other clinical findings are presented in Table 2.

At the second-week control, the platelet count was higher than the admission value, while a significant drop was observed in the WBC and CRP values (Table 3).

The echocardiography findings of 22 (56.4\%) of 39 cases at admission detected coronary artery involvement. Based on the evaluation of the diagnostic criteria, 25 (64.1\%) received a diagnosis of complete Kawasaki disease, and I 4 (35.9\%) were determined to be cases of incomplete Kawasaki disease. The distribution of patients according to age, gender, and diagnosis is provided in Table 4.

When the primary clinical findings were compared, the 
Table I. Distribution of the primary clinical findings

\begin{tabular}{|c|c|c|}
\hline Main findings & $\mathbf{n}$ & $\%$ \\
\hline \multicolumn{3}{|l|}{ Fever } \\
\hline Yes & 39 & 100 \\
\hline No & 0 & 0 \\
\hline \multicolumn{3}{|l|}{ Lip/oral lesions } \\
\hline Yes & 35 & 89.7 \\
\hline No & 4 & 10.3 \\
\hline \multicolumn{3}{|c|}{ Extremity lesions } \\
\hline Yes & 24 & 61.5 \\
\hline No & 15 & 38.5 \\
\hline \multicolumn{3}{|l|}{ Conjunctivitis } \\
\hline Yes & 30 & 76.9 \\
\hline No & 9 & 23.1 \\
\hline \multicolumn{3}{|l|}{ Rash } \\
\hline Yes & 29 & 74.4 \\
\hline No & 10 & 25.6 \\
\hline \multicolumn{3}{|c|}{ Lymphadenopathy } \\
\hline Bilateral & 4 & 10.2 \\
\hline Ipsilateral & 20 & 51.3 \\
\hline None & 15 & 38.5 \\
\hline
\end{tabular}

Table 2. Other clinical findings

\begin{tabular}{lcc}
\hline Other findings & $\mathbf{n}$ & $\%$ \\
\hline Perineal desquamation & 9 & 23.1 \\
Murmur & 4 & 10.3 \\
Sterile pyuria & 3 & 7.7 \\
Arthralgia & 3 & 7.7 \\
Diarrhea & 3 & 7.7 \\
Hepatomegaly & 2 & 5.1 \\
Hepatosplenomegaly & 1 & 2.6 \\
Hydropic gallbladder & 1 & 2.6 \\
\hline
\end{tabular}

incidence of extremity changes, conjunctivitis, and unilateral lymphadenopathy was found to be statistically significantly greater in patients with classic, complete Kawasaki disease $(p=0.001, p=0.005, p=0.029$, respectively) (Table $5)$. The echocardiography results revealed coronary artery involvement in $85.70 \%$ of patients with incomplete Kawasaki disease, which was statistically significantly higher than the $32 \%$ of those with classic Kawasaki disease (Table 6).

Following diagnosis, a single intravenous dose of $2 \mathrm{~g} / \mathrm{kg}$ immune globulin was given to all of the patients as a 12 hour infusion, and oral treatment with acetylsalicylic acid
Table 3. Laboratory values of the patients

\begin{tabular}{|c|c|c|c|}
\hline & Min-Max & Mean $\pm S D$ & $\mathbf{p}$ \\
\hline \multicolumn{4}{|c|}{ Hemoglobin (gr/dL) } \\
\hline Admission & $8.1-12.6$ & $10.39 \pm 1.06$ & 0.087 \\
\hline 2nd week & $7.8-12.1$ & $10.08 \pm 1.19$ & \\
\hline \multicolumn{4}{|l|}{ Hematocrit (\%) } \\
\hline Admission & $26.2-36.5$ & $31.16 \pm 2.70$ & 0.722 \\
\hline 2nd week & $24-36.1$ & $30.97 \pm 3.08$ & \\
\hline \multicolumn{4}{|c|}{ Platelet $\left(\times 10^{3} / \mathrm{mm}^{3}\right)$} \\
\hline Admission & 83-996 & $399.95 \pm 207.57$ & 0.001 \\
\hline 2nd week & $278-1161$ & $598.4 I \pm 227.30$ & \\
\hline \multicolumn{4}{|c|}{ WBC $\left(\times 10^{3} / \mathrm{mm}^{3}\right)$} \\
\hline Admission & $6.3-26.5$ & $15.04 \pm 5.75$ & 0.001 \\
\hline 2nd week & $5.5-23.54$ & $11.92 \pm 4.60$ & \\
\hline \multicolumn{4}{|l|}{ PNL (\%) } \\
\hline Admission & $18-84$ & $59.90 \pm 17.82$ & - \\
\hline \multicolumn{4}{|l|}{ CRP (mg/dL) } \\
\hline Admission & $4.8-207$ & $108.29 \pm 7 \mid .77$ & 0.001 \\
\hline 2nd week & $2.9-104$ & $16.77 \pm 23.10$ & \\
\hline \multicolumn{4}{|l|}{ ESR (mm/hour) } \\
\hline Admission & $10-140$ & $60.10 \pm 33.06$ & 0.514 \\
\hline 2nd week & $10-132$ & $62.97 \pm 29.63$ & \\
\hline \multicolumn{4}{|l|}{ ALT (U/L) } \\
\hline Admission & $4-17 \mid$ & $38.8 I \pm 34.27$ & \\
\hline \multicolumn{4}{|l|}{ AST (U/L) } \\
\hline Admission & $5-203$ & $54.4 \pm 40.75$ & \\
\hline \multicolumn{4}{|l|}{ Albumin (g/dL) } \\
\hline Admission & $2.2-4.82$ & $3.59 \pm 0.61$ & \\
\hline \multicolumn{4}{|c|}{ Sodium (mmol/L) } \\
\hline Admission & $|23-| 4 \mid$ & $134.38 \pm 3.9$ & \\
\hline
\end{tabular}

ALT: Alanine aminotransferase; AST: Aspartate aminotransferase; CRP: Creactive protein; ESR: Erythrocyte sedimentation rate; PNL: Polymorphonuclear leukocyte; WBC: White blood cell; Min: Minimum; Max: Maximum; SD: Standard deviation.

(Bayer Aspirin; Bayer AG, Leverkusen, Germany) was initiated at a daily dose of $80 \mathrm{mg} / \mathrm{kg}$ given at 6-hour intervals. Five patients whose fever recurred or persisted despite treatment were given a second dose of IVIG treatment. When the fever persisted despite the second dose of IVIG treatment in I patient, and an increase in pericardial effusion was detected in a second echocardiogram in another patient, methylprednisolone treatment at a daily dose of 2 $\mathrm{mg} / \mathrm{kg}$ was initiated and maintained for 21 days based on the recommendation of the cardiology department. No instance of myocardial infarction or death occurred in any of the study patients. 
Table 4. Distribution of the diagnoses of incomplete and complete Kawasaki disease

\begin{tabular}{|c|c|c|c|}
\hline & \multicolumn{2}{|c|}{ Kawasaki disease } & \multirow[t]{3}{*}{$\mathbf{p}$} \\
\hline & Complete & Incomplete & \\
\hline & n (\%) & n (\%) & \\
\hline \multicolumn{4}{|l|}{ Age } \\
\hline$\leq 12$ months & I (4.0) & $4(28.6)$ & 0.047 \\
\hline$>12$ months & $24(96.0)$ & $10(7 \mid .4)$ & \\
\hline \multicolumn{4}{|l|}{ Gender } \\
\hline Male & $16(64.0)$ & $13(92.9)$ & 0.064 \\
\hline Female & $9(36.0)$ & I (7.I) & \\
\hline
\end{tabular}

Table 5. Evaluation of the clinical findings

\begin{tabular}{|c|c|c|c|}
\hline & \multicolumn{2}{|c|}{ Kawasaki disease } & \multirow[t]{3}{*}{$\mathbf{p}$} \\
\hline & Complete & Incomplete & \\
\hline & n (\%) & n (\%) & \\
\hline \multicolumn{4}{|l|}{ Lesions of the } \\
\hline lips/oral mucosa & $24(96.0)$ & II (78.6) & 0.123 \\
\hline Extremity lesions & $21(84.0)$ & $3(2 \mid .4)$ & 0.001 \\
\hline \multicolumn{4}{|c|}{ Bilateral nonpurulent } \\
\hline conjunctivitis & $23(92.0)$ & $7(50.0)$ & 0.005 \\
\hline Rash & $20(80.0)$ & $9(64.3)$ & 0.446 \\
\hline \multicolumn{4}{|l|}{ Lymphadenopathy } \\
\hline Bilateral & $4(16)$ & $0(0)$ & 0.029 \\
\hline Unilateral & $15(60)$ & $5(35.7)$ & \\
\hline None & $6(24)$ & $9(64.3)$ & \\
\hline
\end{tabular}

Table 6. Evaluation of coronary artery involvement

\begin{tabular}{|c|c|c|c|}
\hline & \multicolumn{2}{|c|}{ Kawasaki disease } & \multirow[t]{3}{*}{$\mathbf{p}$} \\
\hline & Complete & Incomplete & \\
\hline & n (\%) & n (\%) & \\
\hline $\begin{array}{l}\text { Coronary artery } \\
\text { involvement }\end{array}$ & $8(32.0)$ & $14(100)$ & 0.001 \\
\hline
\end{tabular}

\section{DISCUSSION}

Most (74.4\%) of our study population consisted of male patients; the male/female ratio was 2.9 . In a study performed by Scott et al. ${ }^{\left[{ }^{[9]}\right.}$ in the USA, the mean age of the patients was 3 years (range: $0.2-16$ years). In our study, consistent with the literature, $92.3 \%$ of the patients were younger than 5 years of age. Our youngest patient was 3 months old.

A gradual increase in the annual number of cases was observed during the interval of 2008 to 2013 . This may be related to both an increase in the potential causes of Kawasaki disease, the etiology of which we do not fully know, as well as more diagnostic examinations and easy access echocardiographic tests. A greater incidence of this disease has been reported to occur in the winter and spring months. ${ }^{[5]}$ However, in a study performed by Lee et al. ${ }^{\left[{ }^{[0]}\right]}$ in Taiwan,a greater incidence was detected during the summer months. Studies performed in our country have yielded varied results. In 2 studies performed in the province of Istanbul, the diagnosis of Kawasaki disease was made most frequently during the winter and spring months. ${ }^{[11,12]}$ In our study, the diagnosis of Kawasaki disease most often occurred in June. In a study performed by Topçu et al. ${ }^{\left[{ }^{[3]}\right]}$ in the province of Ankara, similarly, the most frequent months of Kawasaki disease diagnosis were in the winter and spring.

Ece et al. ${ }^{[14]}$ reported that $62 \%$ of their patients were diagnosed during the acute phase and $35 \%$ in the subacute phase of the disease. In our study, $84.6 \%$ of the patients were diagnosed during the acute phase and $15.4 \%$ during the subacute phase.

In our study, the oral cavity and lip lesions observed in $89.7 \%$ of the patients, and the conjunctival congestion seen in $76.9 \%$ were the most frequent findings after fever, while a skin rash was detected in $74.4 \%$, and $61.5 \%$ had extremity lesions or lymphadenopathy. Similarly, conjunctival congestion and oral/lip lesions were the most often reported manifestations in other studies performed in different regions of the country. ${ }^{[15,16]}$ In other studies performed both in our country and abroad, lymphadenopathy was the least frequently reported diagnostic criterion. ${ }^{[17,18]}$ In the present study, while cervical lymphadenopathy was detected in $61.5 \%$ of the patients, it was the least frequently seen symptom. Perrin et al. ${ }^{[19]}$ reported a lower incidence rate for peripheral extremity lesions, conjunctivitis, and skin rashes in incomplete Kawasaki disease compared with the complete form of the disease. In our study, the incidence of lip and oral cavity mucosa lesions and rashes was not significantly different between the 2 forms of Kawasaki disease; however, the rate of encountering extremity lesions, nonpurulent conjunctivitis, and unilateral lymphadenopathy was statistically significantly higher in patients with complete Kawasaki disease.

Concomitant symptoms that are not included in the diagnostic criteria of Kawasaki disease may also be observed. In our study, we detected perineal desquamation in 9 patients, arthralgia in 3 , gastroenteritis in 3 , sterile pyuria in 3 , and gallbladder hydrops in I patient. All of these symptoms were healed without sequelae. 
The most frequently encountered laboratory findings were thrombocytosis, leukocytosis, mild anemia, and elevated ESR and CRP values. In other studies performed in our country too, leukocytosis, anemia, and thrombocytosis were observed in patients diagnosed with Kawasaki disease. $[11,16,17]$ In cases of Kawasaki disease, the ESR and CRP values are almost always increased. In our study, the mean ESR value was $60 \mathrm{~mm} /$ hour, and the mean CRP was $108 \mathrm{mg} / \mathrm{dL}$.

The most important prognostic factor in Kawasaki disease is coronary artery involvement. Among the most frequently detected cardiac lesions, coronary artery dilation, aneurysm, and pericardial effusion have been reported. ${ }^{[10,20]}$ In various studies performed in our country, the incidence of a coronary artery abnormality has ranged from $13 \%$ to $33 \% .{ }^{[12,15,21-23]}$ In our study, echocardiography results indicated coronary artery involvement in $56.4 \%$ of the cases. A similar incidence rate of coronary artery anomalies has been reported in patients with classic and incomplete Kawasaki disease. However, in the present study, coronary artery involvement was observed in all cases with the incomplete form and only $32 \%$ of complete Kawasaki disease cases.

IVIG and acetylsalicylic acid have been found to be quite effective in the treatment of Kawasaki disease. ${ }^{[3,24,25]}$ As noted by many authors, with effective treatment during the acute period, the incidence of coronary artery lesions drops from $25 \%$ to $30 \%$ to just $3 \%$ to $5 \% .^{[3,25]}$ If the fever persists 36 hours after the administration of standard IVIG and acetylsalicylic acid, then an infusion of a second dose of IVIG is recommended. Some $10 \%$ to $15 \%$ of cases are refractory to the first dose IVIG treatment. ${ }^{[26]}$ In cases of persistent fever following the second dose IVIG, the use of steroids, plasma exchange, infliximab, and cyclophosphamide has been reported. ${ }^{[18]}$ In our study, steroid treatment was called for in 2 cases, and a second dose of IVIG was required for 5 patients. Myocardial infarction or death did not occur.

\section{Conclusion}

Kawasaki disease should be considered in the differential diagnosis of patients presenting with fever lasting for more than 5 days that cannot be explained otherwise, especially in those younger than 5 years of age, and the use of echocardiography should be considered, since early diagnosis may prevent the development of cardiac complications.

\section{Ethics Committee Approval}

The approval of the local Ethics Committee was obtained.

Informed Consent

Retrospective study.

Peer-review

Internally peer-reviewed.

\section{Authorship Contributions}

Concept: M.G., Y.A.; Design: M.G., Y.A, E.Ç.K; Data collection \&/or processing: M.G, E.Ç.P., H.K.; Analysis and/ or interpretation: M.G, A.K.; Literature search: M.G, A.K., E.Ç.K, E.Ç.P, H.K.; Writing: M.G, E.Ç.K., A.K.; Critical review: M.G., Y.A., E.Ç.K, E.P., A.K., H.K.

Conflict of Interest

None declared.

\section{REFERENCES}

1. Kawasaki T. Acute febrile mucocutaneous syndrome with lymphoid involvement with specific desquamation of the fingers and toes in children. Arerugi 1967;16:178-222.

2. Aykan HH, Özkutlu S. Kawasaki Hastalığı. In: Yurdakök M, editor. Yurdakök Pediatri. Ankar: Güneş Tip Kitabevi; 2017. p. 3215-24.

3. Newburger JW, Takahashi M, Gerber MA, Gewitz MH, Tani LY, Burns JC, et al. Diagnosis, treatment, and long-term management of Kawasaki disease: a statement for health professionals from the Committee on Rheumatic Fever, Endocarditis and Kawasaki Disease, Council on Cardiovascular Disease in the Young, American Heart Association. Circulation 2004;110:2747-71. [CrossRef]

4. Park MK. Kawasaki Disease. Pediatric Cardiology for Practitioners. 5th ed. Philedelphia: Mosby Elsevier; 2008, p. 367-76.

5. American Academy of Pediatrics. Kawasaki Disease. In: Kimberlin DW, Brady MT, Jackson MA, Long SS, editors. Red Book: 2015 Report of the Committee on Infectious Diseases. 30th ed. Elk Grove Village: American Academy of Pediatrics; 2015. p. 667-76.

6. Tizard EJ, Suzuki A, Levin M, Dillon MJ. Clinical aspects of 100 patients with Kawasaki disease. Arch Dis Child 1991;66:185-8.

7. Burns JC, Capparelli EV, Brown JA, Newburger JW, Glode MP. Intravenous gamma-globulin treatment and retreatment in Kawasaki disease. US/Canadian Kawasaki Syndrome Study Group. Pediatr Infect Dis J 1998;17:1144-8. [CrossRef]

8. Rowley AH, Gonzalez-Crussi F, Shulman ST. Kawasaki syndrome. Rev Infect Dis 1988;10:1-15. [CrossRef]

9. Scott JS, Ettedgui JA, Neches WH. Cost-effective use of echocardiography in children with Kawasaki disease. Pediatrics 1999;104:e57.

10. Lee MH, Dai ZK, Lee MS, Hsu JH, Chuang HY, Wu JR. The recommended frequency of echocardiography in follow-up evaluation of patients with Kawasaki disease. Acta Paediatr Taiwan 2005;46:346-51.

11. Arat C, Acar Y, Türkmenoğlu Y, Sayar T, Hamilçıkan SB, Sazak $\mathrm{S}$, et al. Kawasaki disease: review of 21 cases. Cukurova Med J 2016;41:97-104. [CrossRef]

12. İnalhan M DS, Oral M, Temel Ö, Ünlütürk Ö, Seren LP, Savaş İ. Kawasaki Hastalığı Tanılı Olgularımızın Değerlendirilmesi. Ege Pediatri Bülteni 2006; 3:9-14.

13. Topçu S, Akgün Doğan Ö, Öz N, Tanır G. Clinical Evaluations of 49 Cases with Kawasaki Disease: A Retrospective Cohort Study. J Pediatr Inf 2014;8:64-70. [CrossRef]

14. Ece A, Guneş A, Tan İ, Uluca U, Kelekci S, Yel S, et al. Kawasaki disease: Evaluation of 13 cases. Dicle Tip Dergisi 2013;40:95-9.

15. Ozyurek R, Levent E, Ulger Z, Gurses D. Kawasaki Hastalı̆̆ı: 11 vakanın degerlendirilmesi. Çocuk Sağlığı ve Hastalıkları Dergisi 2004;47:167-71.

16. Binnetoğlu K, Kuşdal Y, Altun G, Babaoğlu K. The Clinical and Epi- 
demiologic Features of Kawasaki Disease in Kocaeli Region: Results of 24 Patients. Çocuk Enf Derg 2010;4:71-5. [CrossRef]

17. Kayiran SM, Dindar A, Gurakan B. An evaluation of children with Kawasaki disease in Istanbul: a retrospective follow-up study. Clinics (Sao Paulo) 2010;65:1261-5. [CrossRef]

18. Alexopoulos A, Vekiou A, Lycopoulou L, Tavena A, Lagona E, Kakourou T. Kawasaki disease in Greek children: a retrospective study. J Eur Acad Dermatol Venereol 2013;27:580-8. [CrossRef]

19. Perrin L, Letierce A, Guitton C, Tran TA, Lambert V, Koné-Paut I. Comparative study of complete versus incomplete Kawasaki disease in 59 pediatric patients. Joint Bone Spine 2009;76:481-5. [CrossRef]

20. Al-Harbi KM. Kawasaki disease in Western Saudi Arabia. Saudi Med J 2010;31:1217-20.

21. Kanra G CA, Kara A, Seçmeer G, Ceyhan M. Kawasaki Hastalığı:
Dokuz vakanın takdimi. Çocuk Sağlığı ve Hastalıkları Dergisi 1999;42:469-78.

22. Ozdemir H, Ciftçi E, Tapisiz A, Ince E, Tutar E, Atalay S, et al. Clinical and epidemiological characteristics of children with Kawasaki disease in Turkey. J Trop Pediatr 2010;56:260-2. [CrossRef]

23. Ergüven M. Yasa O, Kral A, Bulut Ö. Evaluation of Epidemiological, Laboratory Measure- ments, Clinical and Prognostic Features, Treatments and Echocardiographies of Our Patients with Kawasaki Disease. Çocuk Dergisi 2010;10:86-9. [CrossRef]

24. Kawasaki T. Kawasaki disease. Acta Paediatr 1995;84:713-5.

25. Bhatnagar SK, Paul G, Subramanian R, Al Hosni MS, Al Khusaiby SM. Kawasaki disease in Oman-a clinical study. J Trop Pediatr 2003;49:361-6. [CrossRef]

26. Kim DS. Kawasaki disease. Yonsei Med J 2006;47:759-72. [CrossRef]

\section{Kliniğimizde Kawasaki Hastalığı Tanısı İle Yatan Hastaların Değerlendirilmesi}

Amaç: Kawasaki hastalığı çocukluk çağının en sık vaskülitik hastalıklarındandır. Bu çalışmada, kliniğimizde altı yıllık bir süreçde Kawasaki hastalığı tanısı alan olguların değerlendirilmesi amaçlandı.

Gereç ve Yöntem: Ocak 2008-Aralık 2013 tarihleri arasında hastanemiz çocuk kliniğinde Kawasaki hastalığı tanısı ile tedavi edilen 39 olgu geriye dönük olarak değerlendirildi. Olguların demografik özellikleri, klinik, laboratuvar verileri, ekokardiyografi bulguları, aldıkları tedaviler kaydedildi ve istatistiksel olarak değerlendirildi.

Bulgular: Olguların 29'u erkek, 10 'u kız, erkek/kız oranı 2.9 olarak saptandı. Tanı anındaki ortalama yaş $31.82 \pm 20.31$ aydı. Hastaların ikisi 2008 yılında, altısı 2009 yılında, beşi 2010 yılında, yedisi 20I I yılında, I0'u 2012 yılında, dokuzu 2013 yılında tanı aldı. Hastaların \%89.7'sinde dudak ağız mukoza değişiklikleri, \%76.9'unda konjonktivit, \%74.4'ünde döküntü, \%6।.5'inde ekstremite değişiklikleri ve \%6I.5'inde lenfadenopati saptandı. Otuz dokuz olgunun 22'sinde ekokardiyografik incelemede koroner arter tutulumu saptandı. Tanı kriterlerine göre hastaların \%64.I’i klasik Kawasaki, \%35.9'u inkomplet Kawasaki tanısı aldı. Hastalarımızın hiçbirinde miyokart infarktüsü ve ölüm görülmedi.

Sonuç: Gerek komplet gerek inkomplet Kawasaki hastalığı erken tanı konulup tedavi edildiğinde; komplikasyon olarak görülen edinsel kalp hastalıkları engellenebilinir.

Anahtar Sözcükler: Çocuk; inkomplet tip; Kawasaki hastalığı; klinik bulgular; komplet tip. 